\title{
The Politics and Poetics of Oppression in Caryl Churchill's Seven Jewish Children
}

\author{
Amal Gouda Abdel Aziz \\ College of Sciences and Arts, Qassim University, Saudi Arabia \\ goldmermaid9@icloud.com
}

DOI: https://doi.org/10.36892/ijlls.v2i1.163

\begin{tabular}{ll} 
Received: & Abstract \\
$27 / 12 / 2019$ & Caryl Churchill is one of the leading contemporary British playwrights. \\
\hline Accepted: & Because of the Israel military strike on Gaza in early 2009, she wrote her \\
15/3/2020 & short poetic play, Seven Jewish Children, which densely explores modern \\
& Jewish history, from the time of pre-holocaust Europe up to the current \\
& struggles between Israel and Palestinian militant organizations. The \\
Keywords: & stimulating dynamism of Churchill's historical chronicle is that though it \\
Caryl Churchill; Seven & introduces the past suffering of the Jews, it exposes their moral insincerity \\
Jewish Children; & when it comes to labeling the current brutal actions performed by the state of \\
Oppression; & Israel against Palestinian civilians. Employing a descriptive-analytical \\
Palestinian-Israeli & approach, this paper examines the play as a poetic narrative representing a \\
Conflict & pattern of reversed oppression in which contemporary Israelis, descendants of \\
& former victims of the Nazi, have inherited the legacy of the Holocaust and are \\
& deemed accountable for the ruthless violence perpetrated on the Arab \\
& residents of the occupied land.
\end{tabular}

\section{INTRODUCTION}

In response to Israel devastating bombing and ground invasion of Gaza strip in 2009, Caryl Churchill, a preeminent contemporary British playwright, wrote the short and provoking, Seven Jewish Children, A Play For Gaza. The play kept running for about fourteen days in February 2009 at London Royal Court Theatre, later it staged across the United States in New York, Chicago, Washington, Cambridge, Massachusetts, and Los Angeles. The play was promptly subject to contention. Unfortunately, Churchill's appeal for donating to Gaza's children which accompanied the debut of her play confused most of the critics as further evidence of her partiality. Although some British critics appreciated the play, various Jewish commentators fiercely denounced it as anti-Semitic and an incendiary piece against the Jews. The debate intensified when the BBC refused to broadcast the play, based on its responsibility to produce impartiality. However, the play has since been performed in the United States, Australia, and Canada. A Hebrew version of the play was staged in Israel in 2009 as part of a wider campaign organized by a union of progressive groups against the two-year blockade of the Gaza Strip. Besides, several recorded productions of the play have been posted on the internet.

Recognized early in her career as a significant innovative voice, Churchill has been characterized by combining uncompromising sociopolitical commitment with challenging theatrical experimentation. Her recent work not only displays an open dedication to a political issue, but it gives vent to her worries about the damage done to the world by the overwhelming control of global capitalism. Adiseshiah (2012) points out that Churchill's latest plays identify ways by which formerly excluded subjects, those whose role is the part of no part can press for changing the current political co-ordinates. 
Seven Jewish Children was composed a few weeks after the start of Israel's military campaign against Gaza to end Hamas' rocket attacks on Israel. The six-page drama goes past ordinary criticism of Israel, articulating to the Jews of the world its unbending dissent against Israel's current actions. Churchill explained to Mark Brown (2009), the arts correspondent of The Guardian, that she felt compelled to write the drama:

It came out of feeling strongly about what's happening in Gaza - it's a way of helping the people there. Everyone knows about Gaza, everyone is upset about it, and this play is something they come to. It's a political event, not just a theatre event.

Labeling her play "a political event," the play demonstrates its ability to consider a particular political issue, the Israeli-Palestinian in this case, while at the same time symbolically incorporate any similar political struggle against oppression.

Internationally, questions were being raised about the legitimacy and brutality of Israeli strikes on the thickly populated Gaza. Israel's 22-day cast lead operation killed fourteen hundred Palestinians, the majority of which unarmed citizens. Thirteen Israelis were slaughtered, five by friendly fire. A great many Palestinians endured genuine wounds and many were left without sufficient medical care, safe houses, and sustenance. Among the Palestinian dead, more than four hundred were youngsters.

Though Seven Jewish Children alludes to the disconcerting issue of recognizing the historical right to a land populated by ancient Jews and Palestinians, the play does not pass judgment on the problem. Instead, it deals with the conflict as an inescapable struggle between two groups, who are bound to dwell in the same territory. Despite criticizing Israel's excessive use of power, the play suggests to the responsibility of Hamas and other Islamic radical groups who are blamed for the same crime of targeting innocent civilians, albeit on a smaller scale.

\section{SEVEN JEWISH CHILDREN: DISCUSSION}

The text looks more like a lyric than a play. There is much space for ambiguity and uncertainty. The structure of the play poses questions that are not answered. Neither the time nor the place of the action is specified. There are only brief stage directions at the beginning of the text which stress the subtle, allusive nature of the work. The lines are not allotted to specific characters and, as Churchill (2009) states in the published text, they "can be shared out in any way" and the scenes "may be played by any number of actors." Though the author asserts that the characters and the children are different in each scene, she provides no particular features to distinguish their personas. Their gender is obscured, except for the absent children who are girls. However, the play's subtitle, "A Play for Gaza," orients the viewer's minds towards a specific context, that of Palestinian-Israeli conflict.

Corresponding to the cryptic, minimal and poetic expression of the piece, each scene consists of around twenty lines; almost all begin with the imperatives, "Tell her" or "Don't tell her" interspersed with "Don't frighten her"(Churchill, 2009). Though she capitalizes on the beginning of the lines, the author does not use periods at the end of most of these lines. According to Patterson (2009), this provides the play with a back-and-forth quality and establishes a free unbroken rhythm throughout the piece that is similar to a human heartbeat. The language acts as a kind of "linguistic impressionism," Considine (2011, p. 47) maintains, providing numerous brief abstract images of viciousness, panic, and bloodshed that, overall, speak to something more complex and detailed. Furthermore, the verbal simplicity and 
economy of the play, as Kushner and Solomon (2009) point out, are an "implicit rejection of the idea that the situation in the Middle East is too complicated ... to be explored at any length." Choosing an open structure to her play, Churchill leaves it entirely to the director, actors and other artists to decode the play and come up with the final production.

The message in the text, on the other hand, is delivered in dense, implicit and suggestive expressions. There is much that is elusive, tacit and unvoiced. The audiences are invited to fill in the gaps with their own interpretation of the moral and political issues introduced to them in the play. Although it is titled Seven Jewish Children, the children, who receive the uncertain accounts and justifications of their parents, never contribute as active performers. Their existence is masked and oblique, as the text indicates that they should not appear on the stage. Moreover, the Palestinians, though they are absent, yet Churchill's portrayal of them suggests her deep sympathy towards their suffering. This dichotomy of absence and presence, certainty and ambivalence persists throughout the play. Likewise, Leader (2009) notes that Churchill's choice to represent the Jews exclusively and to give no voice to the Palestinians propagates the duality of perpetrator and victim, which leads to a language that others the Palestinians who are the unseen and unheard victims.

Comprising seven short poetic scenes, the play dramatizes the troubled inner discourse of a nation handing on its history to the new generations, yet attempting to protect them from falsehoods and anxiety. Each scene is set in a major period of modern Jewish history, reaching out from the holocaust era, the foundation of the Israeli state, and the displacement of Palestinians, the escalation of the Arab Israeli conflict, and finally landing to the Israeli 2009 military operation and the humanitarian disaster of Gaza that motivated the play. Each succession spotlights on parents or adults debating what to tell or not tell their off-stage child about what is going on and how to clarify a specific rough circumstance to her. Many opposing voices address the argument in question as they struggle to describe war, pain, loss, fear, and hatred to seven absent children. Many of the lines are contradictory, which stresses the risks attending such explanations and suggests that successive adult generations within the Jewish community have varied sentiments and estimations over the crisis-- "Tell her there were people who hated Jews", "Don't tell her that" (Churchill, 2009). The Guardian, however, produced a short video in which a single character plays a variety of antithetic voices and opinions. Articulating the diverse standpoints by one character reflects the inner suspicions in the minds of individual Jews regarding the politics of what is told and what is untold about violence.

Highlighting a compact history of the Jews, Churchill links past events with the contemporary moral messages which directly influence the readers' consciousness and encourages them to react or respond. The play moves quickly from portraying the historical victimization of the Jews in Europe to emphasize a current reversal of position in which the Israeli state becomes the dominant oppressor. Churchill forcefully challenges Jews by revealing their paradoxical situation as victims of long persecution in Europe who morally fail to condemn Israel's latest vicious actions. Friedman (2014) describes the phenomenon as a sort of "moral inversion" which can turn up anywhere. Victims might be perpetrators and right could be wrong. Any historically oppressed group may acquire new power and use it to oppress other groups in turn. Billington (2009) of The Guardian grasped Churchill's notion when he wrote that the piece outlined "in a remarkably condensed form the transformation that overtaken Israel, to the point where security has become the pretext for indiscriminate slaughter." 
By using a diachronic narrative structure, the play can explore the growing ferocity of the conflict. Although historical settings are not identified, Churchill later provided a framework to an American director, Ari Roth (2009). The first scene, she explains, "is set at some time of persecution which could be nineteenth-century Russia... or (as we chose at the royal court) thirtieth Germany." Terror, anxiety, and violence prevail in the scene. It opens with the following lines:

Tell her it's a game

Tell her it's serious

But don't frighten her

Don't tell her they'll kill her

Tell her it's important to be quiet

Tell her she'll have a cake if she's good.

(Churchill, 2009)

It seems that the child is facing the instant danger of arrest and murder by the Nazis. The girl, as well as the adults, are objects of dire circumstances. They have to hide and remain quiet till the persecutors, the source of danger, go away somehow, maybe "By magic (Churchill, 2009). The girl's survival requires that she realizes the severity of the situation without being devastated by it. The adults exert their best efforts as parents and guardians to save the children from physical harm and mental shock as victims of racial oppression.

Scene two is set, according to Churchill's correspondence with Roth (2009), "sometime after the Holocaust in England, or indeed in America." It portrays survivors arguing what to tell the daughter about the death of some family members in the Nazi camps. Losing her uncles and grandmother before she was born, she can only know about them through a photograph. Deeply concerned that their child's awareness of the world may be troubled if they reveal the atrocities of the Nazis against Jews, the adults consider how to remember those murdered relatives in the child's presence: "Tell her her uncle died/ Don't tell her they were killed" (Churchill 2009). The repetition of "Don't tell her what they did," reveals their fear to tell her the truth, whereas "Tell her something"(Churchill, 2009) refers to communicating censored truth to soothe the girl. They are also uncertain whether to ignore their distinctive Jewish identity, "Don't tell her to think Jews or not Jews," (Churchill, 2009) or to inform her there are still people who hate Jews in the world. The task of protecting the child from a memory of evil and misery, too heavy to endure, is definitely problematic. The scene emphasizes the damages caused to humans because of war and racial conflict, resulting in the breakup of families, loss of relatives, and terrible remembrances for the survivors.

Scene three occurs some years later when some Jews from England or America decide to immigrate to Israel. So this most likely relates to a time soon after 1948 when the state of Israel was established. The adults discuss how to tell their little girl their decision without hurting her feeling: "Tell her she can write to her friends, tell her her friends can maybe come and visit" (Churchill, 2009). Jews at this stage acquire increased control over their lives, though they are treated as strangers in post-war England and America, "Don't tell her she doesn't belong here/Tell her... she likes here, but she'll like there even more" (Churchill, 2009). The scene begins with "Don't tell her we're going forever," and continues "Tell her we're going home" (Churchill 2009) suggesting the Jewish anticipations to redeem their lost identity and to end the Jewish diaspora in the newly established state. "Tell her it's sunny there" (Churchill 2009) symbolizes the positive hopes of a prosperous and happy future for the family in Israel. "Tell her it's the land God gave us" (Churchill, 2009) denotes, as Illouz 
(2015), an Israeli sociologist, maintains, that Israeli national consciousness was construed in this sacred frame, a demonstration of a privileged and exceptional relationship between the Jews and God. "Tell her... everyone was driven out and/the country is waiting for us to come home," (Churchill, 2009) underscores the violent inception of the state of Israel and the expulsion of the Palestinians.

The following sequences take place in Israel, whose establishment offered the Jews a feeling of self-control and security that was historically unknown to them for two thousand years. They represent the unease of locating the Jews in Palestine. There is a change in the dialogue as the opposition between affirmative and negative imperatives increases revealing the intensified tension within the Israeli family or community. Scene 4 represents a newly arrived Jewish family to Israel. The adults refer to the difficult relations between Jews and Palestinians, "Don't tell her they don't love her." They raise questions of the right to ownership of the land, ethnicity, and dispossession, "Tell her this wasn't their home", "tell her they're going away", "don't tell her Arabs used to sleep in her bedroom", "Don't tell her she can't play with their children", "Don't tell her she can have them in the house" (Churchill, 2009). "Tell her...this is our promised land" (Churchill, 2009) is a Jewish belief that sanctions Israeli possession of the land. However, a contradictory statement, "Don't tell her religion"(Churchill, 2009) follows indicating moral uncertainties within the Jewish community over using religion to rationalize displacing the Arabs.

The misgivings, however, quickly soften in scene five in the aftermath of the six-day war when the adults cheer up, "Tell her we've won", "Tell her her brother's a hero" and "Tell her how big their armies are" (Churchill, 2009). In this war which broke out in 1967, Israel managed to defeat three Arab countries and to take hold of vast areas of their land: "We've got new land "(Churchill, 2009). This is the shortest scene in the play. It consists of only six lines, four of them contains the subject "we" to underscore the emergence of Israeli military power and dominance in the middle east, "Tell her we're fighters," "Tell her we turned them back"(Churchill, 2009).

Scene six centers on the intensified armed clashes between Israel and Palestinian militant groups. It also focuses on the suffering of the Palestinians as a result of Israel's continuous seizure of land and natural resources. The scene marks the climax of the play as adults forcefully attempts to cover up the vicious truths of moving water away from Palestinian fields to Israeli swimming pools, bulldozing Palestinian houses, destroying their olive trees, shooting down rock-throwing children and building the west bank barrier. The scene consists of 35 lines of which 17 begin with "Don't tell her." This is the largest number of negative imperatives throughout the play's scenes that draw attention to the adults' scruples for there is much to be hidden from the child. Some characters observe the events and try to make sense of them, while others rather prefer to ignore them and struggle to estimate the threat of militant Palestinian groups who "set off bombs in cafes," "want to drive us into the sea," and "don't understand anything except violence" (Churchill, 2009).

Scene seven is the concluding scene and takes place during the 2009 Israeli invasion of Gaza. It begins with the grown-ups striving to protect the youngster from discovering the devastation inflicted on Gaza through Operation Cast Lead. They speak of preventing her from watching the news, denying the child the right to consider Israeli actions on an independent moral basis. "Tell her she can watch cartoons" reveal their desire to keep the girl in a fictional world isolated from reality. Worries about Israeli safety have become the main concern even within the family: "Tell her the army has come to our defense," "Don't tell her how many of them have been killed," "Tell her they're terrorists," "Don't tell her about the 
family of dead girls," "Tell her we killed the babies by mistake" (Churchill, 2009). The adults also refer to the hushing of moderate Israeli voices within as the military has come to control Israeli leadership, "Don't tell her her cousin refused to serve in the army" (Churchill, 2009). Illouz (2015) argues that military security has replaced all political considerations, thus "depriving Israelis of the capacity to see and to grasp the evils carried out in their name."

An extended monologue near the end of the play delivered by a hardline character provides the most aggressive and anti-Arab discourse. It serves as a declaration of the Israeli country's capacity and control, a merciless streamlining of self-protection. Starting as an appeal for truthfulness, it soon becomes an outburst of hatred, racism, and violence: "Tell her...tell her the whole world knows why she shouldn't know?" (Churchill, 2009) Drawing attention to how dehumanizing prolonged warfare can be, it is a clearly anti-Israeli indictment, which arouses charges of anti-Semitism and a blood libel against Churchill:

Tell her...I don't care if we wipe them out, tell her I don't care if the world would hate us, tell her we're better haters, tell her we're the chosen people, tell her I look at one of their children covered in blood and what do I feel? Tell her all I feel is happy it's not her.

(Churchill, 2009)

Although Seven Jewish Children certainly condemns the practices of the state of Israel, there is no suggestion that this should be taken as a critique of all Jewish people. It is possible to find fault with the actions of Israel without being anti-Semitic. The ongoing conflict between Israelis and Palestinians is political rather than religious. Churchill explains to Ari Roth (2009) her basic anti-war and anti-violence stance and also the bitterness she feels due to the historical ironies and injustices experienced by Jews and Palestinians alike: "I am not going to pretend that I am not critical of Israel, or that the play was not written out of anger about Gaza. But it was written out of a more complicated anguish about the whole history, which I know is shared by many Jewish people outside Israel as well as many Israelis." Award-winning dramatist and essayist Tony Kushner and academic journalist and critic Alisa Solomon (2009), both Jewish American critics of modern Israeli politics, defend the monologue as developing from a particular dramatic situation that makes the eruption unavoidable and appalling. In addition, the play's detractors ignore that this violent outburst is followed immediately by the voice of reason: "Don't tell her that / Tell her we love her / Don't frighten her"(Churchill, 2009). These lines closing the play reflect the compassion and fragility of the parents, which outweigh anger and dread. Kushner and Solomon conclude that to detect anti-Semitism here is to interpret inaccurately the words spoken by the worst of Churchill's characters as an announcement from the playwright against all Jews.

"Don't frighten her," (Churchill, 2009) is an injunction often repeated in the play. Atzmon (2009) points out that perhaps the Israelis have a good reason to feel frightened. It took sixty years for their national state to build up its superiority as a state following severe repressive policies. However, the parents' constant attempts not to hurt the child's innocence indicate their guilt-ridden psyche and gives a glimpse of hope that someday they may do something to settle the conflict and achieve real peace between the victims and the victimizers. Admiring Churchill's empathy and sensitivity, Kushner and Solomon (2009) are eventually optimistic relating to the questions that the unseen girls keep asking. They represent the future generations and perhaps someday they may realize that their families' loving desire to protect them by censoring truth is not only unwise but also disastrous. 
Possibly the girl in the final scene will grow up to work for justice and find herself a forerunner of the battle against racism and oppression.

Victimized by the grown-ups' battle to adjust their opposing parts as moral instructors and protectors of the truth, the absent children act as an operative equivalent to the audience who come to be involved in considering the conflict. The audience in any case, unlike the innocent, unsuspecting children, can detect the inconsistencies of the parents' articulations and may realize their deceitful stories which do not always tell the truth; rather they frequently construct "a truth" that fits the national needs at a given time. As Considine (2011) observes, the audience becomes an unidentified character who is associated with the brutal and terrifying struggle by wading into the waves of recurrent imperatives. In that capacity, audience members should endeavor to make a particular vision from the conflicting voices to choose what facts they feel ought to be disclosed and what facts ought to be concealed i.e. they share in forming political propaganda and pass it on to other people. Patterson (2009) likewise argues that the play summons the internal argument of every individual audience. The contentions expressed by the performers, whatever their number may be, suggest that Churchill has created a play that challenges simple interpretations despite its misleadingly short length.

\section{CONCLUSION}

Seven Jewish Children, A Play For Gaza Presents a shortened history of the Jews in which past narratives relate to contemporary moral issues. The play develops a story that records the ascent of the Israeli country from persecuted to oppressor, as security becomes an apology for insensitive onslaught against the Palestinians. Churchill stands up to the Jews, who were liable to broadened maltreatment in Europe, revealing their ethical inability to censure recent Israeli practices. She offers a heated political depiction of the IsraeliPalestinian struggle by endeavoring to give voice to the voiceless, the crushed, and uprooted (the invisible Palestinians) with the goal that they may ascend as talking subjects. The concealed Jewish youths, on the other hand, accentuate the sharp conflict between a set of moral values conferred to them by the grown-ups and different requirements that coordinate the forces at work in the larger Israeli society. Moreover, the absent children, to whom the adults go about as moral guides and monitors of truth, fill in as a basic parallel to the observers who come to be associated with the tactics of expressing the dispute. Dramatizing fragmented tropes of savagery, gore, and fear, the play challenges obvious understandings and urges the viewers to make their own story out of the Palestinian-Israeli crisis.

\section{REFERENCES}

Adiseshiah, S. (2012). Political Returns on the Twenty-first-century Stage: Caryl Churchill's Far Away, Drunk Enough to Say I Love You? and Seven Jewish Children. C21 Literature: Journal of 21st Century Writings, 1(1), 99-117.

Atzmon, G. (2009). From Victimhood to Aggression: Jewish Identity in the Light of Caryl Churchill's Seven Jewish Children. https://www.gilad.co.uk/writings/from-victimhoodto-aggression-jewish-identity-in-the-light-o.html

Billington, M. (2009). Seven Jewish Children. The Guardian. https://www.theguardian.com/stage/2009/feb/11/seven-jewish- children 
Brown, M. (2009). Royal Court Acts Fast with the Gaza Crisis Play. The Guardian. https://www.theguardian.com/stage/2009/jan/24/theatre-gaza-caryl-churchill-royal-court$\underline{\text { seven-jewish-children }}$

Churchill, C. (2009). Seven Jewish Children, A Play for Gaza. https://graphics8.nytimes.com/packages/pdf/world/SevenJewishChildren.pdf

Considine, K. A. (2011). An Implacable Force: Caryl Churchill and the Theater of Cruelty. Unpublished M.A. Dissertation, University of Tennessee, USA.

Friedman, M. (2014). Jewish Self-hatred, Moral Criticism and Autonomy. In M. A. L. Oshana (Ed.), Personal Autonomy and Social Oppression: Philosophical Perspectives (pp. 203222). New York: Routledge.

Illouz, E. (2015). Israel Is in National Denial Regarding its Oppression of Palestinians. Haaretz. https://www.haaretz.com/israel-is-in-national-denial-regarding-its-oppressionof-palestinians-1.5420257

Kushner, T., and Solomon, A. (2009, April 13). Tell Her the Truth: On Caryl Churchill's Seven Jewish Children: A Play for Gaza. The Nation. https://www.thenation.com/article/tellher-truth/

Leader, K. (2009). Tell her to be careful: Caryl Churchill's Seven Jewish Children, A Play for Gaza at the Royal Court Theatre. Platform, 4(1).

Patterson, R. (2009). Caryl Churchill's Seven Jewish Children. The New York Readings. Theatre. $\quad$ https://www.musicomh.com/extra/theatre/caryl-churchills-seven-jewishchildren-the-new-york-readings

Roth, A. (2009). Caryl Churchill's Correspondence with Ari Roth. https://theaterjblogs.wordpress.com/2009/03/24/caryl-churchill-speaks-part-1/

\section{AUTHOR'S BIO:}

Dr. Amal Gouda Abdel Aziz is a Ph. D. holder in literature from the Faculty of Arts, Ain Shames University, Egypt. She currently works as an assistant professor in Unaizah College of Sciences and Arts, Qassim University, Kingdom of Saudi Arabia. 